\title{
Production technology of Nabataean painted pottery compared with that of Roman Terra Sigillata
}

\author{
M. Tite ${ }^{1}$, S. N. Herringer ${ }^{2}$, A. Shortland ${ }^{3}$, M. Matin ${ }^{1}$, T. Pradell ${ }^{4}$, and S. E. Alcock ${ }^{2}$ \\ ${ }^{1}$ Research Laboratory for Archaeology and the History of Art, Dyson Perrins Building, South \\ Parks Road, Oxford OX1 3QY, UK. michael.tite@ rlaha.ox.ac.uk \& \\ moujan.matin@arch.ox.ac.uk.uk \\ ${ }^{2}$ Joukowsky Institute for Archaeology and the Ancient World, Brown University, Box \\ 1837/60 George Street, Providence, RI 02912, USA. susan_herringer@ brown.edu \& \\ susan_alcock@brown.edu \\ ${ }^{3}$ Centre for Archaeological and Forensic Analysis, Cranfield University, Shrivenham, SN6 \\ 8LA, UK. a.shortland@ cranfield.ac.uk \\ ${ }^{4}$ Physics Department and Center for Research in Nano-Engineering, Universitat Politècnica \\ de Catalunya, C/Esteve Terrades 8, 08860 Castelldefels, Barcelona, Spain. \\ trinitat.pradell@upc.edu
}

\begin{abstract}
The Nabataeans, who founded the city of Petra (southern Jordan) in the late first millennium BC, are noted for the production of a distinctive very fine pottery with painted decoration and a wall thickness sometimes as little as $1.5 \mathrm{~mm}$; this pottery appears largely locally made and not widely circulated. Using a combination of OM, SEM with attached EDS, surface XRF, and XRD, it is shown that the Nabataean fine pottery bodies were produced using semi-calcareous clays which were fired to temperatures of about $950^{\circ} \mathrm{C}$. In contrast, published data indicates that contemporary and in many ways apparently functionally equivalent Roman terra sigillata, which was traded throughout the Roman Empire, was produced using fully-calcareous clays which were fired to temperatures in the range $1000-1100^{\circ} \mathrm{C}$. Furthermore, the high gloss slip applied to Roman terra sigillata is fully vitrified whereas the red-painted decoration applied to the Nabataean pottery is unvitrified. The more robust Roman terra sigillata is therefore better suited as tableware for serving and consuming food than would be the case for Nabataean fine pottery, and would be a more successful export material.
\end{abstract}

KEYWORDS: POTTERY, TERRA SIGILLATA, SLIPS, NABATAEAN, ROMAN, CALCAREOUS CLAYS, FIRING TEMPERATURES, OM, SEM-EDS, XRF, XRD

\section{INTRODUCTION}

The Nabataeans, who were originally nomads, founded the city of Petra (southern Jordan) in the late first millennium BC as their royal capital and management centre for trade. It is famed for its rock-cut tombs and temples intricately carved into the pinkish sandstone, giving it its epithet - the 'Rose Red City'. The importance of Petra as a trading centre increased to reach a peak in the last two centuries $\mathrm{BC}$ and first two $\mathrm{AD}$; following the Roman annexation of the Nabataean kingdom in 106 AD, the commercial role of Petra shifted and eventually declined. During their peak period, the Nabataeans produced, for domestic and religious use, fine pottery with wall thickness sometimes as little as $1.5 \mathrm{~mm}$. Although production of such pottery continued post-annexation, the quality declined towards the end of the $2^{\text {nd }}$

centuryC 
$\mathrm{AD}$, with the pottery becoming coarser and thicker. Typical were shallow open bowls which would have required considerable skill to produce on a potter's wheel. This pottery had red bodies which were decorated with dark red to brown to sometimes near black flower and leaf designs. The flower and leaf designs are often found with geometric motifs such as dots and lattices which connect the floral motifs.

The main emphasis of previous research on Nabataean fine pottery has been directed at identifying and distinguishing between the different raw material sources used in its production (Amr 1987, Daszkiewicz et al. 2013), and at replicating the forming, decorating and firing procedures (Mason and Amr 1990, Mason and Amr 1995, Amr et al. 2005). The aim of the present study has been to extend the available analytical data on the raw materials and to investigate the firing temperatures used in the production of Nabataean fine pottery.

A small group of Nabataean sherds from the excavations by Brown University of the Great Temple at Petra (Joukowsky 1998) have been examined using optical microscopy (OM), scanning electron microscopy with attached energy-dispersive spectrometer (SEM-EDS), surface X-ray fluorescence analysis (XRF), and X-ray diffraction (XRD). The results obtained are then compared with corresponding published data for Roman terra sigillata which was traded throughout the Roman Empire, and which was in many respects a ceramic akin in usage to Nabataean fine pottery.

\section{EXPERIMENTAL PROCEDURES}

\section{Samples}

Fourteen Nabataean sherds from the Brown University Great Temple excavations at Petra were selected for examination (figure 1). The majority were open bowl fragments from two separate days of excavation of the Shrine Room and Baroque Room (SRBR) which has been assigned a date range of $1^{\text {st }}$ century $\mathrm{BC}$ to $1^{\text {st }}$ century AD. On the basis of the style of decoration, sherds from 24/VI/02 (MS3-4, MS6, MS9-10) were possibly slightly later in date than those from 29/VI/02 (MS1-2, MS11-13, MS15-16). In addition, a few sherds (MS1819) of similar date range but of varying forms were selected from the excavation of the Corridor between the Settling Tank and Residential Quarter (CSTRQ). It should be noted that this type of pottery is not only found in contexts across the city center, but also commonly in its regional hinterland; it does not, however, appear to have been widely traded beyond (Alcock and Knodell 2012).

\section{Analytical procedures}

Polished cross-sections were prepared from all fourteen sherds. Of these, seven polished cross-sections were examined at Brown University under OM using a Mitutoyo Ultraplan FS110 microscope at magnifications up to 200x, and seven were examined at Oxford and Cranfield Universities with SEM-EDS. The SEM-EDS systems used were a JEOL SEM (JSM-5910) with Oxford Instruments EDS (INCA 300 System) at Oxford University, and a JEOL SEM (JSM-840A) with EDAX EDS at Cranfield University. Both SEM-EDS systems were operated at $20 \mathrm{kV}$ with 120 s measuring times for the EDS analyses. Backscattered electron (BSE) images were obtained in order to study the microstructures of cross-sections, and the EDS systems were operated in the standardless analytical mode. Surface XRF analyses were also make on the slip and body surfaces of four sherds using a benchtop XRF 
(Seiko SEA600X) run at 50kV with a $10 \mathrm{~mm}$ working distance and $1.5 \mathrm{~mm}$ analytical area, and operated in air.

XRD measurements were made on the slip and body surfaces of two sherds (MS12, MS16) at Universitat Politècnica de Catalunya using a conventional diffractometer, Bruker D8 with monochromatic $\mathrm{Cu}-\mathrm{K} \alpha(1.5606 \AA)$ radiation with $4-70$ degrees two theta range, the penetration depth of the X-rays being less than about $100 \mu \mathrm{m}$. Powder XRD measurements were taken from the body of nine other sherds (MS 1, 3-7, 9-10, 14) on a Bruker AXSPowder X-ray Diffractometer at Clark University (Worcester, MA, USA) with $\mathrm{Cu}-\mathrm{K} \alpha$ radiation with a two theta range of $15-60^{\circ}$. Identification of the compounds has been performed based on the Powder Diffraction File (PDF) database from the International Centre for Diffraction Data (ICDD).

Samples of two sherds (MS12 and MS16) were refired in an electric furnace to $950^{\circ} \mathrm{C}$ and $1050^{\circ} \mathrm{C}$, with a heating rate of $300^{\circ} \mathrm{C} / \mathrm{hr}$ and then $1 \mathrm{hr}$ at maximum temperature. These samples were then re-examined in the Oxford SEM, and re-analysed by surface XRD.

\section{RESULTS}

The microstructures of the Nabataean pottery bodies as observed in the SEM reveal open networks of fine, partially vitrified clay filaments containing varying amounts of non-plastic inclusions, the majority of which are quartz and feldspar (figure 2). On the basis of the abundance and size of the inclusions, as observed in both SEM and OM, the sherds can be divided into two fairly distinct groups. In sherds MS1-2, MS11-13 and MS16, the inclusions

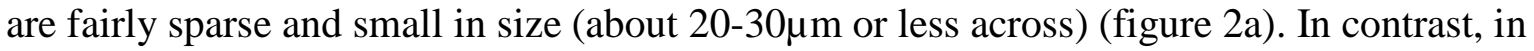
sherds MS3, MS 10, MS15 and MS18-19, the inclusions are more abundant and vary in size from $20 \mu \mathrm{m}$ to about $100 \mu \mathrm{m}$ across (figure $2 \mathrm{~b}$ ).

The body compositions for the Nabataean pottery as determined by SEM-EDS are presented in table 1 from which it is seen that the body clays are characterised by comparatively high iron oxide contents (5-8 wt\%), and intermediate alumina (19-23 wt\%) and lime (5-10 wt \%) contents. Comparison of the compositions for the same sherd (MS12) as determined at Cranfield and Oxford are in good agreement with each other, and also, generally in agreement with the compositions of three Nabataean sherds from Petra assigned to Period III (circa 20 AD to early $2^{\text {nd }}$ century AD) (Schmid 1996, Amr et al. 2005), as determined by wavelength dispersive-XRF and reported by Daszkiewicz et al. (2013) (Table 1).

As observed in cross-section in the SEM, the red painted decoration on sherd MS11 is associated with a very thin, fragmented and unvitrified layer about $10 \mu \mathrm{m}$ thick and containing a scatter of iron oxide particles about $2 \mu \mathrm{m}$ across (Figure 3a). Its composition is characterised by significantly higher iron oxide content (17.9 wt $\% c f .7 .7 \mathrm{wt} \%)$, higher potash content (4.5 wt $\%$ cf. $2.9 \mathrm{wt} \%)$, and lower lime content ( $2.2 \mathrm{wt} \%$ cf. $8.6 \mathrm{wt} \%)$ than that of the body (table 1). Red paint layers were not observed in any of the other sherd samples examined in the SEM. However, for sherds MS12-13 and MS15, subtraction of the surface XRF spectra of the red painted decoration from those for the unpainted bodies confirmed that the red painted decoration is consistently higher in iron oxide and potash, and lower in lime as compared to the corresponding body (figure 4). 
As observed in cross-section in the SEM, the white slip applied to the outer surface of sherd MS19 is associated with a compacted but unvitrified layer about $30 \mu \mathrm{m}$ thick (figure $3 \mathrm{~b}$ ) which is lime-based containing some $85 \mathrm{wt} \% \mathrm{CaO}$ (table 1).

Surface X-ray diffraction measurements on sherds MS12 and MS16, undertaken at Universitat Politècnica de Catalunya, showed that the principal mineral phases present in the bodies are quartz, haematite $\left(\alpha \mathrm{Fe}_{2} \mathrm{O}_{3}\right)$, Ca-Na feldspar $\left.(\mathrm{Ca}, \mathrm{Na}) \mathrm{AlSi}_{3} \mathrm{O}_{8}\right), \mathrm{K}-\mathrm{Na}$ feldspar $\left((\mathrm{K}, \mathrm{Na}) \mathrm{AlSi}_{3} \mathrm{O}_{8}\right)$, akermanite $\left(\mathrm{Ca}_{2} \mathrm{MgSi}_{2} \mathrm{O}_{7}\right)$, and diopside $\left(\mathrm{CaMgSi}_{2} \mathrm{O}_{6}\right)$ (figure 5a) (table 2). Essentially the same range of mineral phases were detected in the bodies of a further nine sherds using powder XRD measurements at Clark University (Worcester, MA, USA. In contrast, because of its very low lime content, the only significant phases detected by surface XRD measurements in the red painted decoration on sherd MS16 are quartz, haematite, and K-Na feldspar (figure 5a) (table2).

The examination of the refired samples of sherds MS12 and MS16 in the SEM showed that the bodies fired to $950^{\circ} \mathrm{C}$ exhibited similar open networks of fine, partially vitrified, clay filaments to those of the as-received sherds with at most a very slight increase in vitrification (figure 6). In contrast, the bodies fired to $1050^{\circ} \mathrm{C}$ exhibited continuous vitrification with bloating pores less than about $50 \mu \mathrm{m}$ across. Similarly, XRD measurements indicated that the range and amounts of the different mineral phases present after refiring to $950^{\circ} \mathrm{C}$ was essentially unchanged, but after firing to $1050^{\circ} \mathrm{C}$, only haematite, $\mathrm{Ca}-\mathrm{Na}$ feldspar and quartz remained with mullite being formed in sherd MS16 (figure 5b) (table 2). It is therefore suggested that the firing temperature employed in the production of the Nabataean fine pottery was about $950^{\circ} \mathrm{C}$.

\section{COMPARISON WITH ROMAN terra sigillata}

Roman terra sigillata was first produced in Italy from mid- $1^{\text {st }}$ century BC. Production then moved to southern Gaul where the most important workshop was at La Graufesenque (Aveyron) and from where terra sigillata was traded throughout the Roman Empire, including around the entire Mediteranean (Sciau et al. 2006).

As observed in the SEM, the microstructures of the terra sigillata bodies, which are thicker (3-4 mm) than those of the Nabataean fine pottery, again reveal an open network of fine, partially vitrified clay filaments containing a scatter of quartz and other non-plastic inclusions (Tite et al. 1982a, Sciau et al. 2006) (figure 7). In contrast to the Nabataean red painted decoration, the high gloss terra sigillata surface slip layer, which is typically 10-20 $\mu \mathrm{m}$ thick, appears vitrified and impermeable with no visible clay structure but a high concentration of iron oxide particles, typically less that $0.5 \mu \mathrm{m}$ in diameter.

The compositions of the terra sigillata bodies (table 3 ) are very similar to those of the Nabataean fine pottery except for somewhat higher lime contents (10-17 wt\% cf. 5-10 wt\%) and slightly lower iron oxide contents (5-6 wt\% cf. 5-8 wt\%). The terra sigillata slips again have higher iron oxide (10-12 wt \% cf. 5-6 wt\%), potash (7-10 wt $\% c f .1-4 \mathrm{wt} \%)$, and alumina (23-33 wt\% cf. 21-23 wt\%) contents, and lower lime contents (1-2 wt \% cf. 10-17 wt \%) than those of the bodies. However, the increase in potash content in the slip is more than that in the case of the Nabataean fine pottery, whereas the increase in the iron oxide content is less. 
On the basis of the changes, as determined by XRD, in the mineral phases present when samples of local clay or terra sigillata are fired or refired, the estimated firing temperature for terra sigillata is in the range $1000-1100^{\circ} \mathrm{C}$ (Sciau et al. 1992, Mirti et al.1999) as compared to about $950^{\circ} \mathrm{C}$ for the Nabataean fine pottery.

\section{DISCUSSION AND CONCLUSIONS}

As contemporary ceramics produced by societies which were definitely in contact with each other, it is interesting to note that the compositions of the Nabataean and Roman terra sigillata bodies and slips are in many respects similar, the principle difference being that the lime contents of the Nabataean bodies $(5-10 \mathrm{wt} \% \mathrm{CaO})$ are less than those of the Roman terra sigillata bodies (10-20 wt\% CaO)

Therefore, as first defined by Maniatis and Tite (1981) and Tite et al. (1982b), the clays used to produce both ceramic groups can, be classified as calcareous (i.e., $>5 \mathrm{wt} \% \mathrm{CaO}$ ), rather than non-calcareous (i.e., < $5 \mathrm{wt} \% \mathrm{CaO}$ ). Maniatis and Tite (1981) further distinguished between fully-calcareous clays containing greater than about $10 \mathrm{wt} \% \mathrm{CaO}$ and semicalcareous clays containing some $5-10 \mathrm{wt} \% \mathrm{CaO}$. For the former, the open network of vitrified filaments observed in the SEM remains essential unchanged over the firing temperature range from $850-1050^{\circ} \mathrm{C}$, whereas for the latter, as observed by the production of of continuous vitrification when the Nabataean bodies, MS12 and MS16, were refired to $1050^{\circ} \mathrm{C}$, the extent of vitrification can start to increase well before $1050^{\circ} \mathrm{C}$.

Therefore, the Nabataean bodies can be classified as semi-calcareous and the Roman terra sigillata bodies as fully-calcareous. However, the open network of vitrified filaments observed in the SEM and the detection of calcium silicate phases by XRD for the Nabataean bodies suggest that there has been sufficient formation of crystalline phases to achieve some of the gains in rigidity and compressive strength resulting from the use of fully-calcareous clays, as for Roman terra sigillata bodies (Peters and Iberg 1978).

The greater thickness of the Roman terra sigillata bodies (3-4 $\mathrm{mm} c f$. as little as $1.5 \mathrm{~mm}$ ), together with their higher lime content, suggests that Roman terra sigillata is both stronger and tougher than Nabataean fine pottery. Furthermore, the high gloss, vitrified slip applied to terra sigillata is clearly more robust than the unvitrified, red paint decoration applied to Nabataean pottery.

In summary, therefore, Roman terra sigillata is more durably suited for tableware for serving and consuming food than would be the case for Nabataean fine pottery, as well as more successfully suitable for long-distance transport.

\section{ACKNOWLEDGEMENTS}

The help provided by the Martha Sharp Joukowsky and the Petra Great Temple Excavations, Brown University; and the Joukowsky Institute for Archaeology and the Ancient World, Brown University is gratefully acknowledged. Funding is gratefully acknowledged for M. Matin from the Keble College (Oxford) Graduate Fund and by an Institute of Archaeology (Oxford) Bursary, and for T. Pradell from CICYT grant MAT2013-41127 and Generalitat de 
Catalunya grant 2014SGR-581. Jon Painter is thanked for assistance in undertaking the SEM analyses at Cranfield University.

\section{REFERENCES}

Alcock, S.E., Knodell, A. 2012. Landscapes north of and nearby Petra: The Petra Area and Wadi Silaysil Survey (Brown University Petra Archaeological Project, 2010-2011), in:

Nehmé, L., Wadeson, L. (Eds.), The Nabataeans in Focus: Current Archaeological Research at Petra. Papers from the Special Session of the Seminar for Arabian Studies held on 29 July 2011 (Supplement to Proceedings of the Seminar for Arabian Studies 42), 5-16.

Amr, K., 1987. The Pottery from Petra. A Neutron Activation Analysis Study. BAR International Series No. 324. BAR, Oxford.

Amr. K., Akasheh, T., Na'es, M., 2005. Recovery and reproduction technology of Nabataean painted fine ware. $4^{\text {th }}$ International Conference on Science and Technology in Archaeology and Conservation, Project CERAMED, pp. 1-12. (Unpublished but a copy can be obtained from Khairieh Amr via Academia.edu)

Daszkiewicz, M., Schneider, G., Schmid, S. G., Bobryk, E., 2013. Grouping of Nabataean pottery from Petra (Jordan) using pXRF and other techniques, in: Hauptmann, A., Mecking, O., Prange, M. (Eds.), Archäometrie und Denkmalpflege 2013. Jahrestagung an der BauhausUniversität Weimar. Metalla (Bochum) 6, 138-142.

Joukowsky, M. S., 1998. Petra: The Great Temple, Volume I - Brown Excavations 19931997. Petra Exploration Fund, Brown University, Providence, RI.

Maniatis, Y., Tite, M.S., 1981 Technological examination of Neolithic-Bronze Age pottery from central and south-east Europe and from the Near East. J. of Archaeological Science 8, $59-76$.

Mason, J.R.B., Amr, K., 1990. A study of Nabataean pottery manufacturing techniques: an experiment for reconstructing the production of fine bowls. Aram 2, 287-307.

Mason, J.R.B., Amr, K., 1995. An investigation into the firing of Nabataean pottery, Studies in the History and Archaeology of Jordan 5, 629-636.

Mirti, P., Appolonia, L., Casoli, A,. 1999. Technological features of Roman Terra Sigillata from Gallic and Italian centres of production. J. Archaeological Science 26, 1427-1435.

Peters, T., Iberg, R., 1978. Mineralogical changes during firing of calcium-rich brick clays. American Ceramic Society Bull. 57, 503-505, 509.

Picon, M., Carre, C., Cordoliani, M. L., Vichy, M., Hernandez, J. A., Migard, J. L., 1975. Composition of the La Graufesenque, Banassac and Montans Terra Sigillata. Archaeometry 17, 191-199. 
Schmid, S.G., 1996. Die Feinkeramik, in: Bignasca, A. et al. (Eds.), Petra - Ez Zantur I. Ergebnisse der Schweizerisch-Liechtensteinischen Ausgrabungen 1988-1922. Phillipp von Zabern, Mainz, Ch. 6.

Sciau, P., Werwerft, M., Vernhet, A., Bemont, C., 1992. Recherche sur les témperatures de cuisson and la nature des engobes des céramiques sigillées de la Graufesenque. Revue d'Archéométrie 16, 89-95.

Sciau, P., Relaix, S., Roucau, C., Kihn, Y., 2006. Microstructural and microchemical characterization of Roman period Terra Sigillata slips from archaeological sites in southern France. J. American Ceramic Society 89, 1053-1058.

Tite, M. S., Bimson, M., Freestone, I. C., 1982a. An examination of the high gloss surface finishes on Greek Attic and Roman Samian wares. Archaeometry 24, 117-126.

Tite, M. S., Maniatis, Y., Meeks, N. D., Bimson, M., Hughes, M. J., Leppard, S. C., 1982b. Technological studies of ancient ceramics from the Near East, Aegean, and Southeast Europe, in: Wertime, T. A., Wertime, S. F. (Eds), Early Pyrotechnology - the evolution of the first fire-using industries. Smithsonian Institution Press, Washington DC. pp. 61-71. 


\section{FIGURE CAPTIONS}

Figure 1 Photos of Nabataean fine pottery sherds examined by OM, SEM-EDS and XRD: (a) MS10 from SRBR24/VI/02, (b) MS12 from SRBR29/VI/02, (c) MS16 from SRBR29/VI/02, (d) MS19from CSTRQ.

Figure 2 SEM photomicrographs of cross-sections through bodies of Nabataean sherds showing open network of fine, partially vitrified clay filaments with (a) fairly sparse and small inclusions (sherd MS11), and (b) more abundant and larger inclusions (sherd MS18).

Figure 3 SEM photomicrographs of cross-sections through slips and bodies of Nabataean sherds showing (a) very thin, fragmented and unvitrified layer containing a scatter of iron oxide particles (white) associated with the red painted decoration on sherd MS11, and (b) compacted but unvitrified layer associated with white slip applied to sherd MS19.

Figure 4 Observed surface XRF spectrum for Nabataean sherd MS15 after subtraction of the spectrum for the red painted decoration from that for the unpainted body, showing lower calcium, and higher potassium and iron in the red painted decoration.

Figure 5 XRD spectra for (a) painted and unpainted areas of the surface of Nabataean sherd MS16, and (b) unpainted areas of the surface of Nabataean sherd MS16 after refiring to $950^{\circ} \mathrm{C}$ and $1050^{\circ} \mathrm{C}$.

Figure 6 SEM photomicrographs of cross-sections through bodies of Nabataean sherds MS12 and MS16 showing in both cases little change in the open network of fine, partially vitrified clay filaments visible in the as-received (ASR) microstructure and after refiring to $950^{\circ} \mathrm{C}$, but a significant change to a continuously vitrified microstructure with bloating pores after refiring to $1050^{\circ} \mathrm{C}$.

Figure 7 SEM photomicrograph of cross-section through slip and body of Roman terra sigillata sherd BRH1 showing vitrified, impermeable slip layer approximately $20 \mu \mathrm{m}$ in thickness and containing iron oxide particles (white) (LHS), and open network of fine, partially vitrified clay filaments in the body (RHS). 


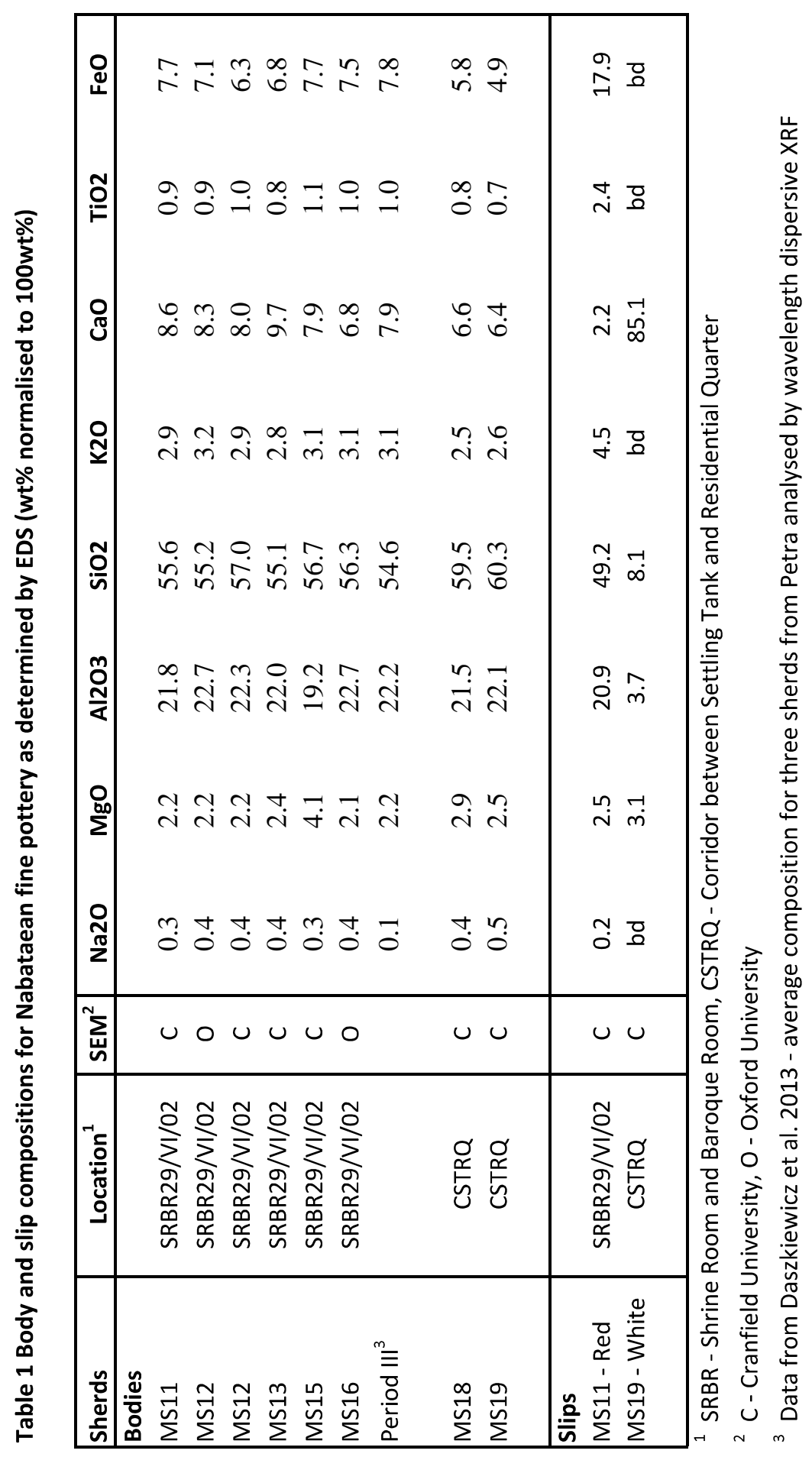




$$
\text { I }
$$




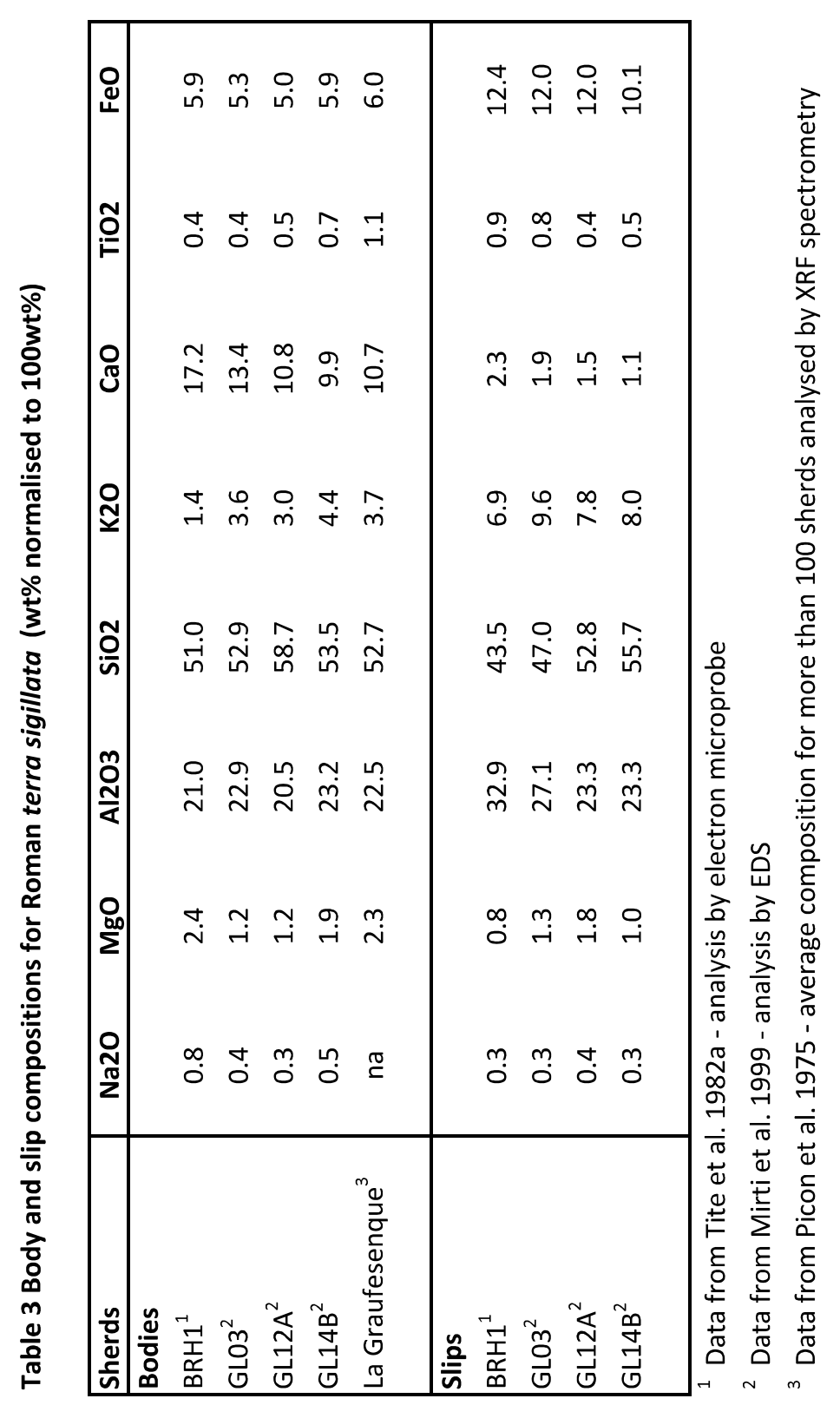


Figure 1

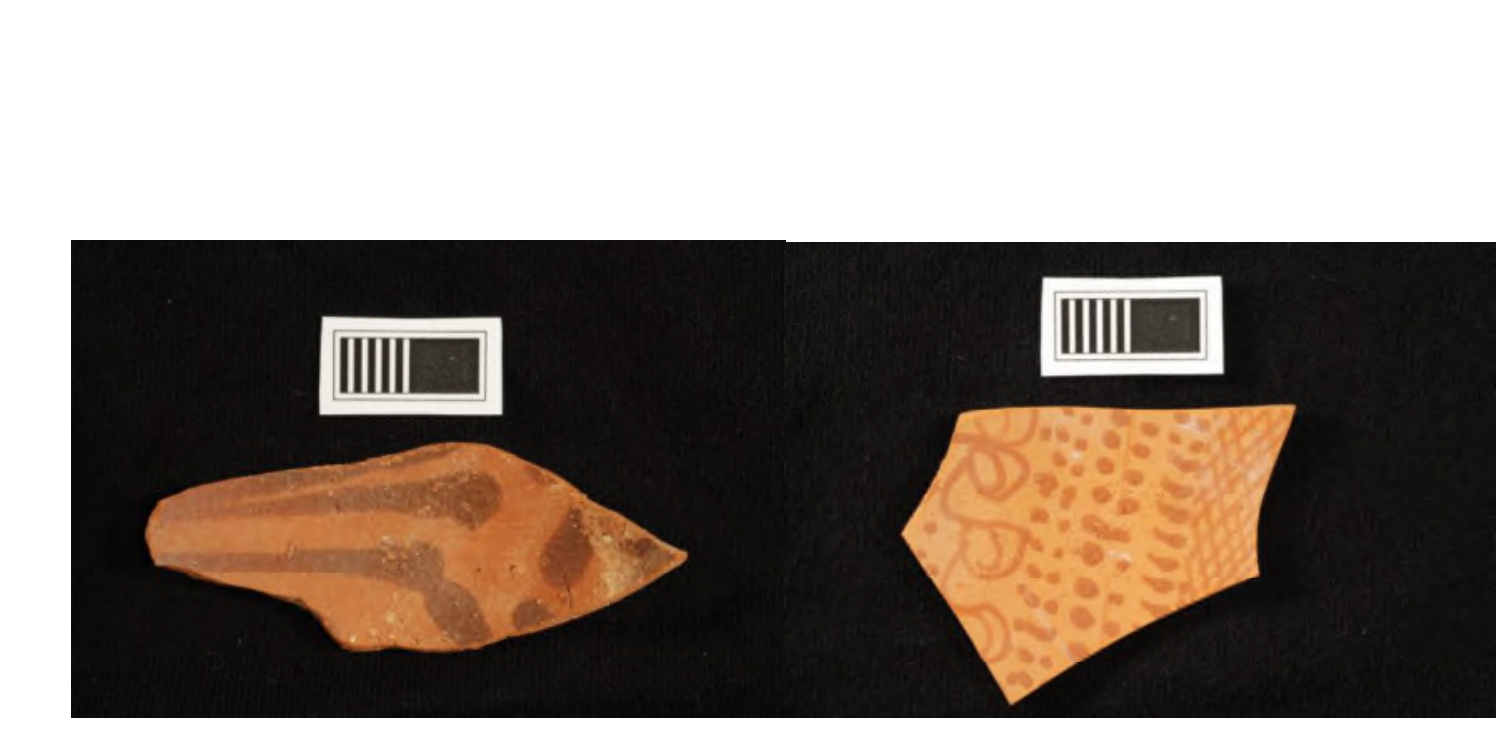

Figure 1a

Figure 1a

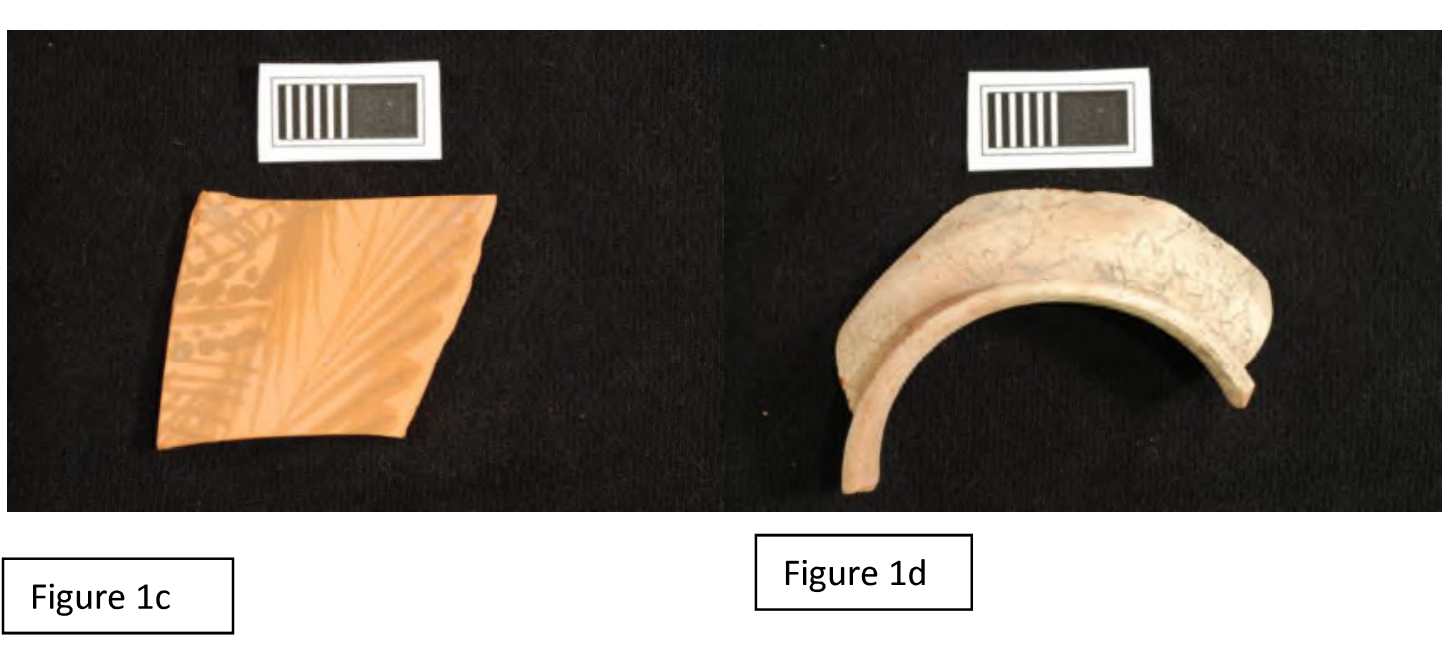

Figure 1c

Figure 1d

Figure 1c

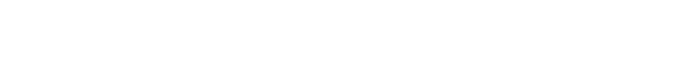

IIII

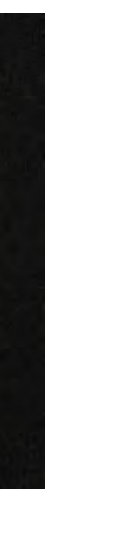
Figure 1d

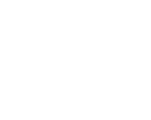

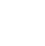

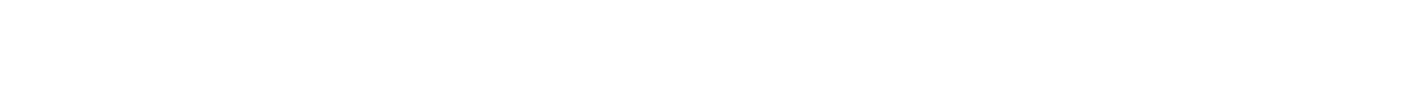




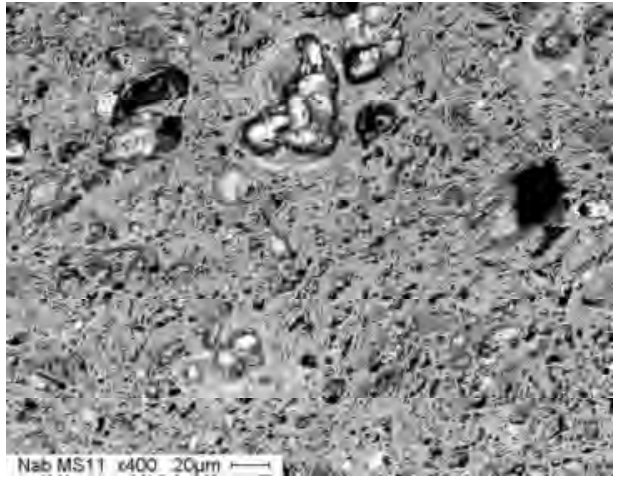

Figure 2a

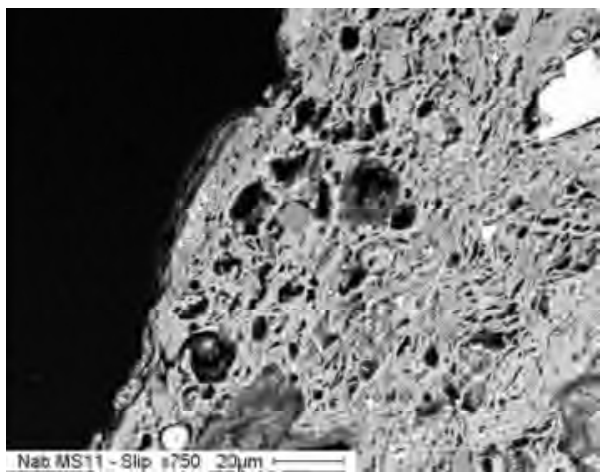

Figure 3a

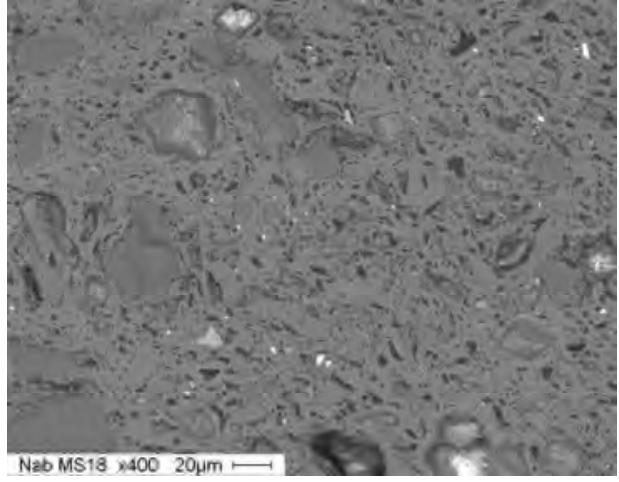

Figure $2 b$

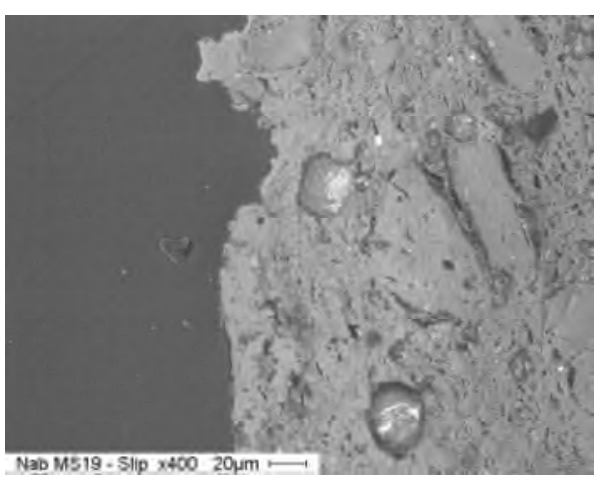

Figure $3 b$

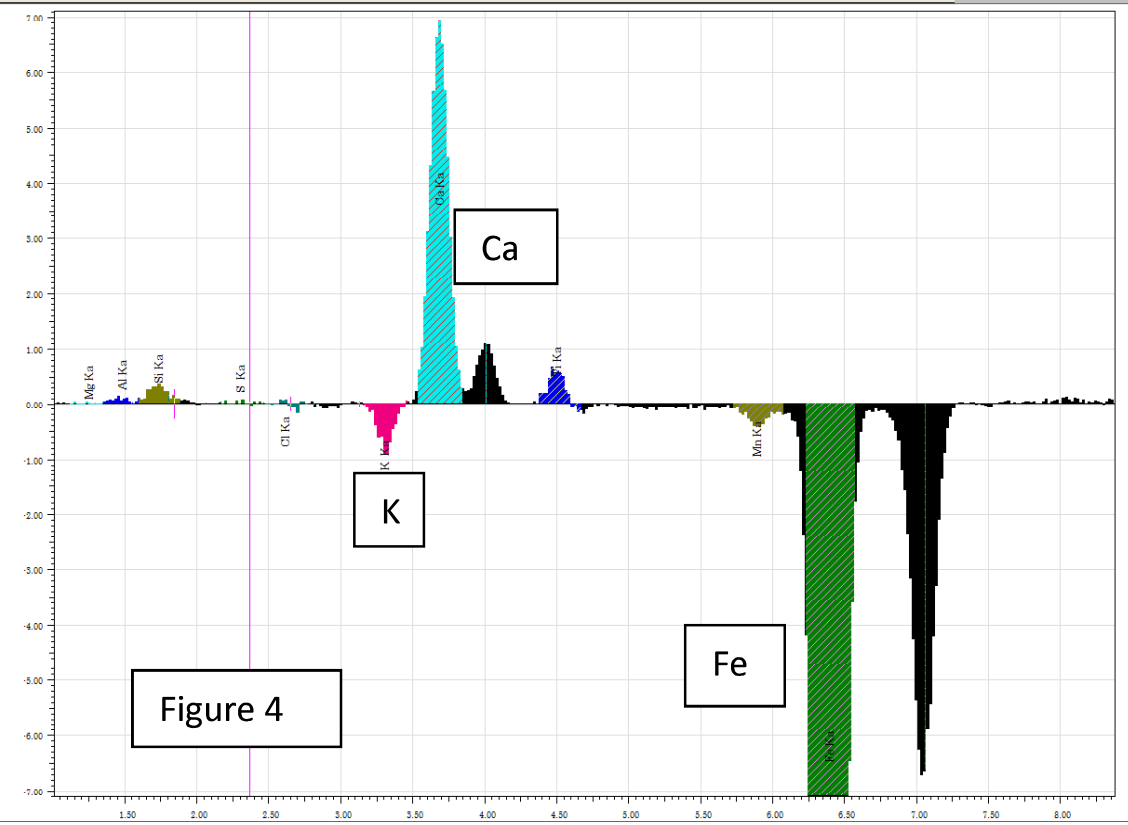


Ca-Na feldspar - $(\mathrm{Ca}, \mathrm{Na}) \mathrm{AlSi}_{3} \mathrm{O}_{8}$

$\mathrm{K}$-Na feldspar - $(\mathrm{K}, \mathrm{Na}) \mathrm{AlSi}_{3} \mathrm{O}_{8}$

akermanite - $\mathrm{Ca}_{2} \mathrm{MgSi}_{2} \mathrm{O}_{7}$

diopside - $\mathrm{CaMgSi}_{2} \mathrm{O}_{6}$

calcite - $\mathrm{CaCO}_{3}$

hematite - $\mathrm{Fe}_{2} \mathrm{O}_{3}$

kaolinite - $\mathrm{Al}_{2} \mathrm{Si}_{2} \mathrm{O}_{5}(\mathrm{OH})_{4}$

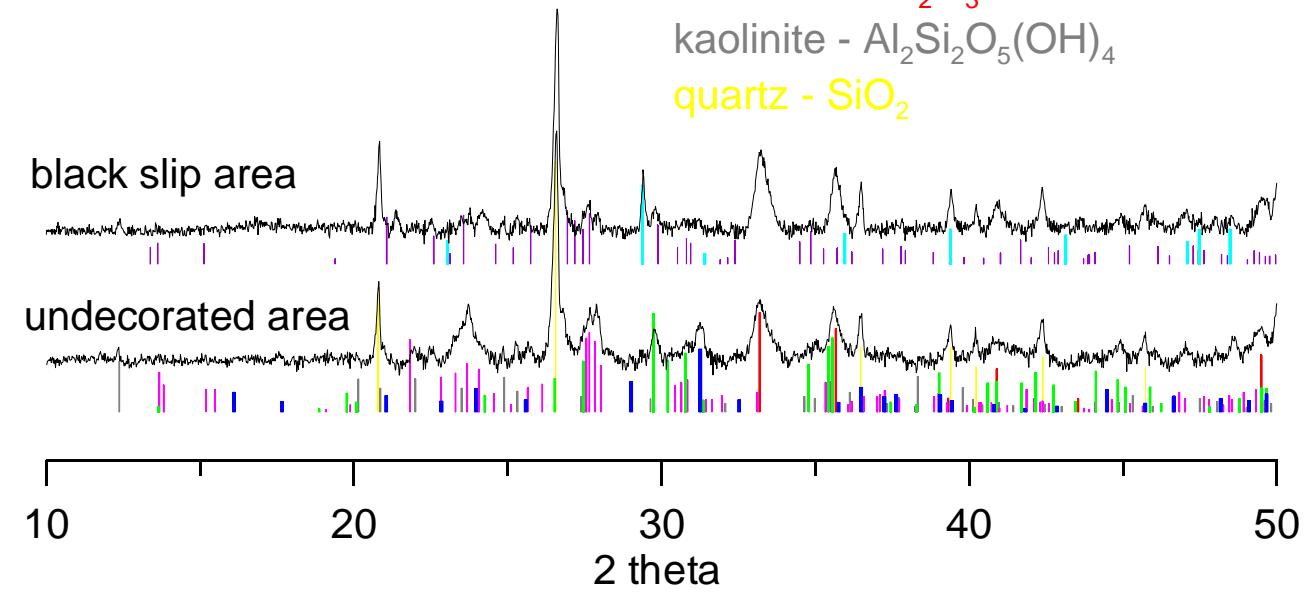

Figure $5 b$

Ca-Na feldspar - (Ca,Na) $\mathrm{AlSi}_{3} \mathrm{O}_{8}$ $\mathrm{K}-\mathrm{Na}$ feldspar - $(\mathrm{K}, \mathrm{Na}) \mathrm{AlSi}_{3} \mathrm{O}_{8}$ parawollastonite - $\mathrm{CaSiO}_{3}$ akermanite $-\mathrm{Ca}_{2} \mathrm{MgSi}_{2} \mathrm{O}_{7}$

diopside - $\mathrm{CaMgSi}_{2} \mathrm{O}_{6}$ haematite $-\mathrm{Fe}_{2} \mathrm{O}_{3}$ spinel - $\mathrm{Al}_{2} \mathrm{MgO}_{4}$

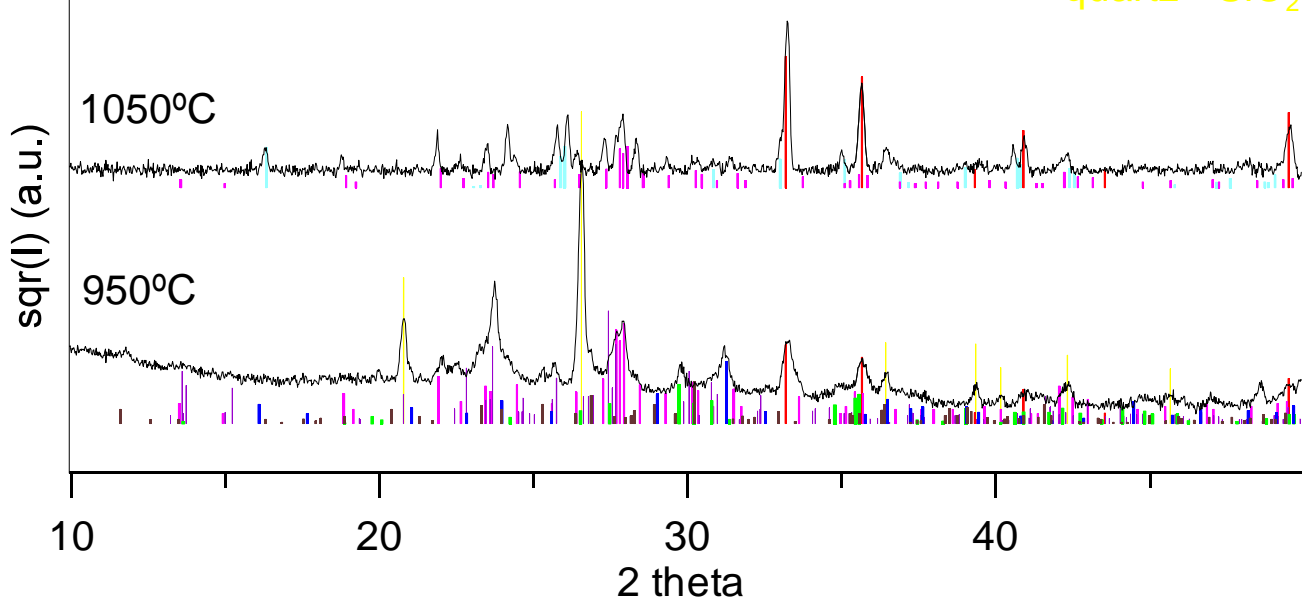



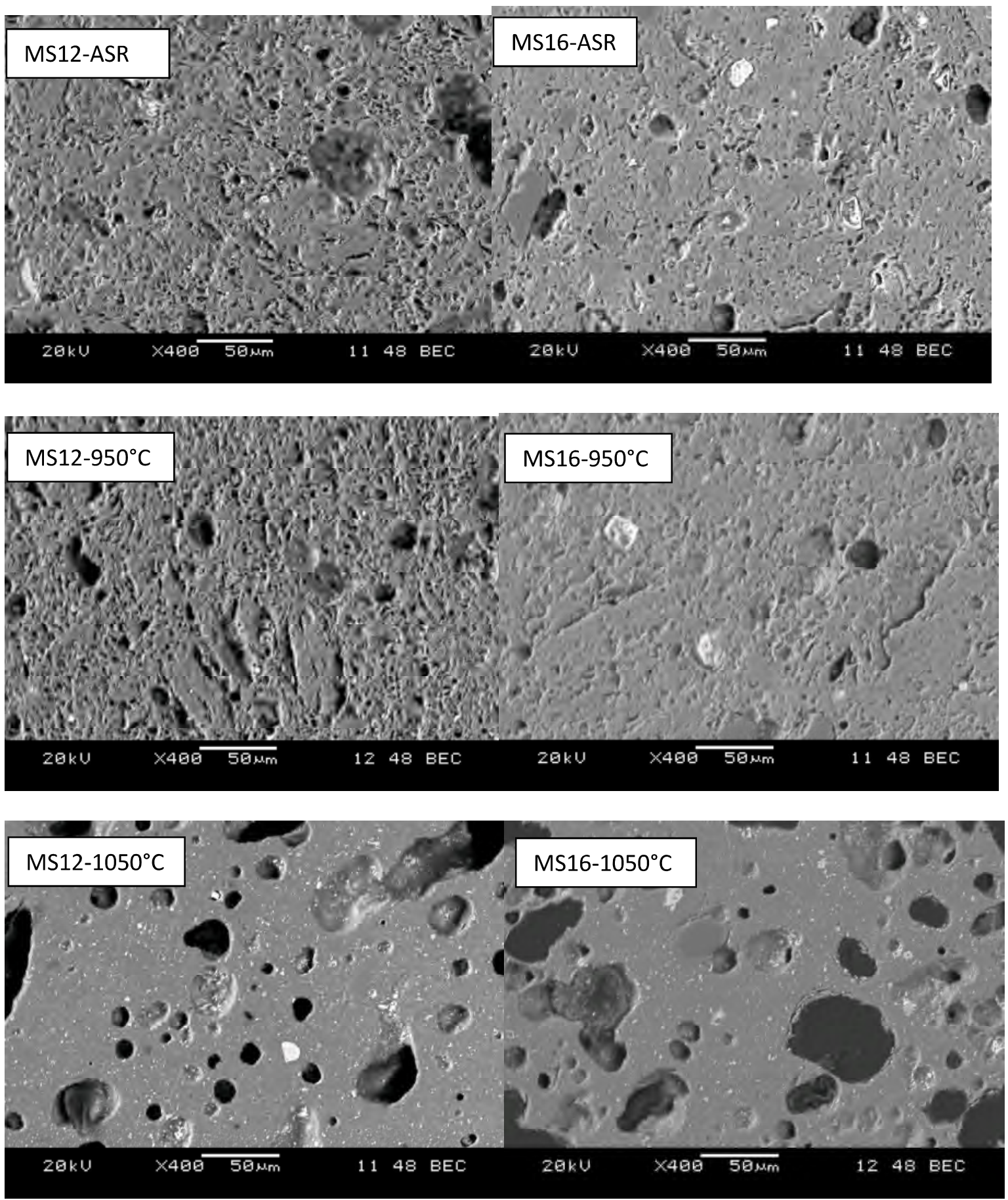

Figure 6 


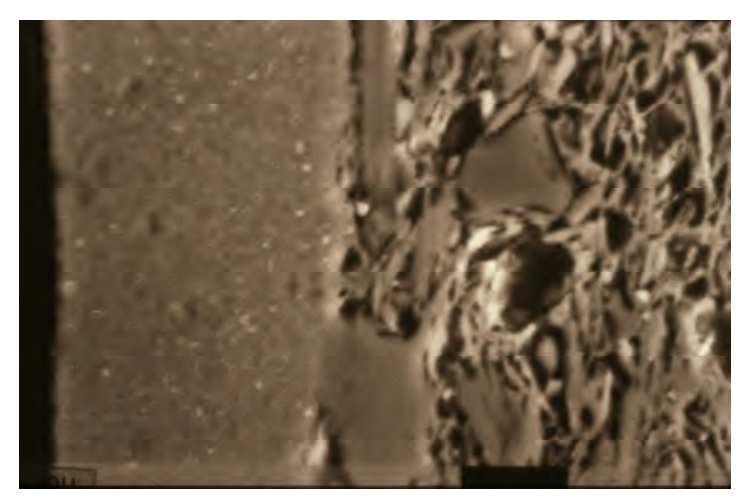

Figure 7 


\section{NABATAEAN POTTERY - HIGHLIGHTS}

- Nabataean fine pottery produced from semi-calcareous clay and fired to $950^{\circ} \mathrm{C}$

- Crystalline phases in Nabataean pottery increase rigidity and compressive strength

- Roman terra sigillata produced from fully-calcareous clay and fired to $1000-1100^{\circ} \mathrm{C}$

- Roman terra sigillata stronger than Nabataean pottery, and better utilitarian ware 